\title{
UMA EXPERIÊNCIA CRUZADA PELAS ÁGUAS DO PARÁ: A FAMÍlIA DE TURQUIA NO TAMBOR DE MINA
}

\section{AN EXPERIENCE CROSSED BY THE WATERS OF PARÁ: THE FAMILY OF TURKEY IN THE DRUM OF MINE}

\author{
UNE EXPÉRIENCE TRAVER ÉE PAR LES EAUX DE PARÁ: \\ LA FAMILLE DE TURQUIE DANS LE TAMBOUR DE LA MINE
}

Taissa Tavernard de Luca ${ }^{1}$

\section{Resumo}

Mosaniel Reis Costa ${ }^{2}$

O presente artigo tem por objetivo apresentar a mitologia construída sobre a família de Turquia no Estado do Pará, uma das mais importantes cultuadas dentro do panteão da religião de matriz africana mais antiga de Belém: a mina. Analisa principalmente sua organização estabelecendo uma comparação com as narrativas registradas no Maranhão. Estas entidades são consideradas "encantadas' que compõe uma realeza aristocrática não europeia e não cristã. Eles possuem ligação com o episódio histórico das Cruzadas, a ocupação das rotas de comércio para as Índias e o processo de expansão para o novo mundo. A mitologia constrói-se numa epopeia de exaltação ao mar e às atividades náuticas. Neste sentido buscamos associar mitologia e história para entender a lógica de adoração dos Turcos pelas religiões afro-brasileiras no eixo norte cultural. Os dados são coletados a partir um Terreiro denominado Terreiro de Nagô Nossa Senhora da Conceição liderado pelo sacerdote Mosaniel Reis Costa, descendente da linhagem da maranhense mãe Inês (sobrenome desconhecido), um dos mitos de origem da gênese religiosa do Tambor de Mina no Estado.

\section{Palavras Chave: Religião Afro-Paraense, Mina, Mito, Simbolismo do Mar}

Abstract

This article aims to present the mythology built on the family of Turkey in the State of Pará, one of the most important worshiped within the pantheon of the oldest African religion in Belém: the mine. It mainly analyzes your organization establishing a comparison with the narratives recorded in Maranhão. These entities are considered "enchanted" that make up a non-European and non-Christian aristocratic royalty. They are linked to the historic episode of the Crusades, the occupation of trade routes to the Indies and the process of expansion into the new world. Mythology is built on an epic of exaltation to the sea and nautical activities. In this sense, we seek to associate mythology and history to understand the logic of worship of Turks by Afro-Brazilian religions in the cultural north axis. The data are collected from a Terreiro called Terreiro de Nagô Nossa Senhora da Conceição led by priest Mosaniel Reis Costa, descendant of the lineage of Maranhão's mother Inês (unknown surname), one of the myths of origin of the religious genesis of the Tambor de Mina in the State.

\footnotetext{
${ }^{1}$ Doutora em Antropologia, Membro do Instituto Histórico e Geográfico do Pará (cadeira no 2 - Patrono Alexandre Rodrigues Ferreira) Professora do Programa de Pós-graduação em Ciências da Religião da Universidade do Estado do Pará e do Programa de Pós-Graduação em Sociologia e Antropologia da UFPA. E-mail. taissaluca@gmail.com

${ }^{2}$ Sacerdote do Tambor de Mina Paraense, Iniciado por Raimundo Nonato Moura (pai Raimundo Branco) e Raimunda Prudenciana (Mãe Raimundinha), Neto de Santo de Francisco dos Reis (Chico Légua) e Inês (Sobrenome Desconhecido). Descendente do Terreiro de Nagô Nossa Senhora Santana. Liderança do Terreiro de Nagô Nossa Senhora da Conceição. Membro da Federação Espírita, Umbandista e dos Cultos Afro-Brasileiros do Pará. E-mail. musanielreiscosta@gmail.com
} 


\section{Uma experiência cruzada pelas águas do Pará: \\ A família de Turquia no tambor de Mina}

\section{Keywords: Afro-Paraense Religion, Mine, Myth, Symbolism of the Sea Abstrait}

Cet article a pour but de présenter la mythologie bâtie sur la famille de la Turquie dans l'État du Pará, l'une des plus vénérées au panthéon de la plus ancienne religion africaine de Belém: la mine. Il analyse principalement votre organisation en établissant une comparaison avec les récits enregistrés à Maranhão. Ces entités sont considérées comme "enchantées» et constituent une royauté aristocratique non européenne et non chrétienne. Ils sont liés à l'épisode historique des croisades, à l'occupation des routes commerciales vers les Indes et au processus d'expansion dans le nouveau monde. La mythologie est construite sur une épopée d'exaltation à la mer et aux activités nautiques. En ce sens, nous cherchons à associer mythologie et histoire pour comprendre la logique du culte des Turcs par les religions afro-brésiliennes dans l'axe culturel nord. Les données sont collectées à partir d'un Terreiro appelé Terreiro de Nagô Nossa Senhora da Conceição dirigé par le prêtre Mosaniel Reis Costa, descendant de la lignée de la mère de Maranhão Inês (nom inconnu), l'un des mythes de la genèse religieuse du Tambor de Mina dans l'État

\section{Mots-clés: Religion Afro-Paraense, Mine, Mythe, Symbolisme de la Mer.}

Este texto tem por objetivo retomar um trabalho iniciado em 2005, quando uma de suas autoras começou a se dedicar a entender a cosmovisão do Tambor de Mina. Esta religião, presente no eixo norte nordeste, se caracteriza pela adoração a um panteão hibrido que congrega deuses africanos como os voduns (divindades dahomeanas) e orixás (divindades yorubanas), personagens históricos notáveis que participaram do processo de expansão marítima e colonização ibérica - denominados de senhores de toalha ou nobres gentis nagôs - e entidades mestiças, conhecidas de cabocos ${ }^{3}$.

O primeiro intento era, abordar, nos limites de uma tese de doutorado (defendida em 2010), todas as categorias de entidades devocionais do Tambor de Mina, o que se tornou impossível dada a riqueza e a vastidão mitológica. Outra dificuldade encontrada, à época, foi construir um modelo unificando narrativas diferentes. Muitas casas de culto foram contempladas por aquela pesquisa e cada sacerdote construía sua própria versão sobre as entidades. Era impossível sistematizar, a partir da diversidade, a composição das famílias.

Fazendo um recorte, nos debruçamos sobre a realeza ibérica que compunha o conjunto de deuses e encantados da mina paraense. Coletamos narrativas desses personagens, correlacionamos mito e história, refletimos sobre símbolismos com destaque para a branquidade, a pedra, a água, os animais.

Restou-nos a dívida de completar a reflexão sobre o panteão. Dez anos se passaram e muita transformação foi vivenciada por aquela pesquisadora que, de distante transformou-se em próxima, sendo iniciada no Terreiro de Nagô Nossa Senhora da Conceição, pelo Sacerdote Mosaniel Reis Costa, também autor do presente texto.

O processo iniciático, longe de atrapalhar a pesquisa etnográfica, comprometendo o pretenso (e inacessível) mito da objetividade, permitiu fazer recorte de uma casa de santo e consequentemente de uma

\footnotetext{
${ }^{3}$ Utilizaremos o termo caboco e não caboclo para privilegiar a nomenclatura utilizada pela comunidade que despreza a regra culta da língua portuguesa 


\section{Uma experiência cruzada pelas águas do Pará: \\ A família de Turquia no tambor de Mina}

versão narrativa, bem como conhecê-la a fundo posto que não se trata mais apenas de um "objeto de estudo" e sim de um elemento devocional.

Para legitimar um texto escrito por religiosos recorremos às críticas realizadas pela antropologia moderna e pós-moderna (GEERTZ, 1989; CLIFFORD, 2002 etc) ao mito da objetividade da ciência antropológica que levou autores como Clifford Geertz (1989) a afirmar que a etnografia é uma descrição densa realizada a partir da perspectiva hermenêutica, que lê e interpreta a realidade cultural como um texto. Neste sentido, seja o autor um estranho ou um membro integrado ao campo de pesquisa estudado, o resultado de sua observação será sempre uma interpretação que filtra a realidade pelas lentes de seu referencial teórico ou de sua vivência.

Assumimos a ousadia autoetnográfica, certos de seu potencial acadêmico e dividimos a autoridade etnográfica (Clifford, 2002) entre as duas categorias de saberes compõe o fazer antropológico: o conhecimento tradicional e o conhecimento acadêmico. Consideramos o escrever sobre o outro uma ação política que historicamente empodera o dono da pena e destitui o poder da fala. Quem narra os mitos, vivencia os modelos, produz o sistema cultural transforma-se em "objeto de estudo", reproduzindo o velho e empoeirado esquema durkheimiano de "transformar o fato social em coisa" (DURKHEIM, 2009). Em contrapartida, ao antropólogo que escuta e elabora os modelos, cabe os louros da construção teórica e da divulgação acadêmica. Constrói-se uma hierarquia de conhecimento que submete a oralidade à escrita.

Em oposição a esse esquema, acreditamos em uma horizontalidade de saberes onde a narrativa do mito e a prática cultural não está posta abaixo da construção teórica e da análise do simbólico. Desta forma

unificamos o conhecimento nativo a teoria antropológica escrevendo um texto a quatro mãos. Cabe ao sacerdote a funções de contar a histórias sobre os Turcos e direcionar os rituais e à pesquisadora observar, sistematizar e teorizar o que é vivenciado a luz da antropologia.

Este artigo tem por objetivo analisar a composição e a história de uma família específica, adorada pelo panteão do tambor de mina; a Família de Turquia, a luz do que é vivenciado e contado nos limites do Terreiro de Nossa Senhora da Conceição, situado no bairro de Castanheira, mais precisamente a Passagem Santa Cruz, $n^{\circ} 152$. Este foi escolhido a partir do pertencimento dos autores que ocupam o papel de pai e filha de santo da casa e por seu vínculo de linhagem com um dos mitos de origem do "Tambor de Mina" no Pará, o Terreiro de Nagô Nossa Senhora Santana, abaixo apresentado. O templo pesquisado encontra-se em sua segunda geração tendo sido fundado por Mãe Izabel Maria Silva Pantoja e atualmente liderado por pai Mosaniel Reis Costa.

\section{O TAMBOR DE MINA: UMA RELIGIÃO AFRO- AMAZÔNICA}

A religião de origem africana mais antiga radicada em território paraense é inegavelmente o Tambor de Mina. O período histórico das origens remete ao final do século XIX, conhecido pela historiografia como da economia gomífera. Trata-se de uma manifestação religiosa cujas características étnicas advém do antigo 
reino do Daomé (República Popular do Benim) trazidas por negros radicados no antigo Estado do Maranhão e Pará (posterior Grão-Pará e Maranhão).

Conforme já foi fartamente mencionado por pesquisadores africanistas (FERRETTI, 1993; VERGOLINO, 2000, 2003; LUCA, 2010), o termo mina faz referência ao maior empório o de escravos sob domínio português: o Forte São Jorge de El’ Mina, situado na Costa do Ouro, atual Gana, que exportava mãode-obra negra para diversas partes do Brasil (VERGOLINO, 2003).

No Estado do Maranhão estes negros fundaram duas casas mater: a Casa das Minas - de tradição jeje - e a Casa de Nagô - com influência da tradição Nagô, em meados do século XIX. Além destes dois centros de culto, considerados pela bibliografia específica, como pioneiros mencionamos, também outros terreiros, de fundação um pouco mais tardia que tiveram importância fundamental em se tratando desta matriz religiosa. Referimo-nos ao Terreiro da Turquia - fundado por mãe Anastácia - e o Terreiro do Egito - criado por Massinokô-Alapong. Outro grande centro exportador de tradição é a cidade de Codó, situada no leste do Estado do Maranhão, cuja ênfase era dada ao culto dos encantados (VERGOLINO, 2003).

Foi do Maranhão que os mineiros migraram para Belém, em duas etapas: a primeira composta pelos religiosos maranhenses atraídos pela economia gomífera e a segunda constituída por paraenses que foram para o Maranhão buscar iniciação durante a década de 70 e 80 do século XX (LUCA, 2010). Nesse processo histórico muitos nomes de casas tradicionais e sacerdotes são mencionados como pioneiros. Nenhum deles nascidos em continente africano, mas todos oriundos do hoje, vizinho, estado do Maranhão.

Dentre os nomes de religiosos e templos sagrados destacamos três. O primeiro é o Terreiro de Nagô Santa Barbara, fundado em 1891 pela Senhora Rosa Viveiros (Mãe Doca). O templo localizava-se na travessa Humaitá entre Avenida Duque de Caxias e Avenida Visconde de Inhauma, bairro da Pedreira ${ }^{4}$. Esta senhora, que recebia Toya Jotin, Vó Missã e Caboclo Inambé, é reconhecida pela comunidade afro-religiosa local como mito de origem das religiões afro-brasileiras na Amazônia. Foi iniciada pelo Nigeriano de Nupê, Manoel Teu Santo (VERGOLINO, 2003) e irmã de santo de mãe Anastácia, fundadora do famoso Terreiro da Turquia em São Luís do Maranhão.

Na sequência citamos Terreiro de Mina Dois Irmãos - antigo Terreiro de Santa Bárbara - localizado na Rua Pedreirinha, periférico bairro do Guamá 5 , fundado em $1890^{6}$ pela maranhense oriunda do Codó mãe Josina (Sobrenome Desconhecido) que recebia o vodum Verequete. Trata-se do único terreiro centenário ainda hoje em funcionamento na capital paraense e atualmente tombado pelo Patrimônio Histórico Estadual (LUCA, 2010).

\footnotetext{
${ }^{4}$ Bairro periférico da cidade de Belém, habitado, em grande parte, pela população negra e reconhecido como "bairro do samba e do amor". Nele estavam localizados a grande maioria dos terreiros fundadores de Belém. Até os dias atuais concentra grande quantidade de templos afro-brasileiros. Por ser referência para o samba, neste bairro foi construído o sambódromo da capital, onde, em tempos de carnaval, desfilam as escolas de samba.

${ }^{5} \mathrm{O}$ bairro do Guamá é um bairro da periferia de Belém, que também concentra grande população negra e mestiça. No século XIX, quando mãe Josina abre o referido terreiro, o bairro se caracterizava por ser uma área quase rural, cercada de mata, localizada nos arredores da cidade, longe do centro urbano.

${ }^{6}$ Essa data de fundação não é consenso em meio a comunidade afro-brasileira que considera mãe Doca como pioneira.
} 
Por último mencionamos o Terreiro de Mina Nagô Nossa Senhora Santana, conhecido como Terreiro da Cocada, localizado na Passagem Texeira (antiga passagem da Cocada) no - também periférico - bairro da Cremação ${ }^{7}$, fundado pela Maranhense do Rosário, mãe Inês (Sobrenome Desconhecido), que recebia Lokô Maia e Vó Missã. Esta sacerdotisa iniciou sua carreira religiosa pelas mãos de Manuel Teu Santo, sendo tal qual Mãe Doca, irmã de santo da fundadora do Terreiro da Turquia, com quem mantinha contato estreito. Posteriormente concluiu sua carreira religiosa "pagando obrigação" com uma sacerdotisa maranhense conhecida como Joana da Castanheira.

Dos três terreiros acima mencionados, o primeiro e o segundo são fartamente mencionados pela bibliografia africanista local (LEACOCK, 1972; VERGOLINO, 1976; LUCA, 2010, etc...). O Primeiro e o ultimo estão extintos. Mãe Doca iniciou apenas um filho de santo conhecido como Gino de Xangô Pingo de Ouro $^{8}$, que faleceu antes dela. O Terreiro Dois Irmãos está na quarta geração (terceira geração uterina), tendo passado de Mãe Josina para mãe Amelinha ${ }^{9}$ (sua filha de santo), desta para mãe Lulư ${ }^{10}$ (filha carnal de mãe Amelinha), e de mãe Lulu para mãe Eloisa ${ }^{11}$ (filha carnal de mãe Lulu).

O último, apesar de extinto, mantém sua linhagem viva até os dias atuais através do sacerdote Mosaniel Reis Costa (pai Musa), que lidera o Terreiro de Nagô Nossa Senhora da Conceição, atualmente com possui 57 anos de fundação. Este sacerdote foi iniciado pelo senhor Raimundo Nonato Moura (pai Raimundo Branco), filho de santo do conhecido pai de santo maranhense Francisco dos Reis (Chico Légua) ${ }^{12}$. Posteriormente concluiu sua carreira religiosa "pagando obrigação" 13 com mãe Raimunda Prudenciana, mãe Raimundinha, filha de mãe Inês (sobrenome desconhecido) e sucessora do Terreiro da Cocada.

Conforme é possível observar, o tambor de mina praticado no Estado do Pará não possui as suas origens vinculadas aos primeiros terreiros Maranhenses, os tradicionais Querebetã de Zomadonu (Casa das Minas) ou a Casa de Nagô. Sua tradição remete ao Terreiro da Turquia através da figura de Mãe Anastácia,

\footnotetext{
${ }^{7}$ Bairro situado na periferia de Belém que recebe esse nome, por abrigar, em 1901, o forno crematório de lixo da cidade. Consta que no período da Belle Époque um dos problemas que incomodava o processo de urbanização e até europeização da capital da borracha era a grande quantidade de dejetos que se amontoava pelas ruas da cidade atrapalhando os planos do então intendente Antônio Lemos, de transformar Belém na Paris da América (https://www.oliberal.com/crema\%C3\%A7\%C3\%A3o-de-quando-se-buscava-solu\%C3\%A7\%C3\%B5es-para-o-lixo1.53618). Neste sentido o governante instalou, nos arredores do centro urbano - local de moradia da população pobre e não branca - a maior e mais moderna usina crematória da América Latina, que conferiu nome ao bairro.

${ }^{8}$ Segundo informações concedidas pelo Senhor Antônio Gomes da Cruz, mãe Doca teria “ajeitado" o Xangô de Gino, que descia em terra "parece um sapo".

${ }^{9}$ Carmelina Amâncio Neto

${ }^{10}$ Luíza Ninfa de Oliveira

${ }^{11}$ Eloiza Oliveira

${ }^{12}$ Chico Légua era conhecido pela população afro-religiosa por seus trabalhos de alta magia. Recebia os senhores Seu Pedro Angaço e Rainha Rosa bem como o caboco Légua. Por essas entidades, percebe-se que possuía estreita Ligação com a família da mata do Codó. Seu Chico Légua morreu assassinado por um afeto que o matou com o punhal de seu Exu. Consta que no dia do seu enterro o bairro da Pedreira (onde ele morava) parou e seguiu em cortejo.

${ }^{13}$ A Carreira sacerdotal no Tambor de Mina, assim como em outras matrizes religiosas afro-brasileiras é marcada pelo assentamento de anjo de guarda, pela iniciação e pelo pagamento de obrigação. Quando o filho-de-santo recolhe-se ao terreiro e se submete a rituais que, em linhas gerais, significam a renovação dos votos iniciáticos.
} 


\section{Uma experiência cruzada pelas águas do Pará: \\ A família de Turquia no tambor de Mina}

fundadora do referido templo sagrado que constantemente visitava a capital paraense com a finalidade de rever parentes religiosos, auxiliar em processos iniciáticos e fundação de templos.

Outro centro de exportação de tradição foi a cidade interiorana do Codó, cidade de nascimento de Mãe Anastácia, que recebeu grande número de negros cambinda. Do terreiro da Turquia herdamos uma das famílias de entidades mais tradicionais cultuadas no Tambor de Mina; a família da Turquia - aqui estudada - e do Codó adveio a chamada família de Codó ou família de Légua, cultuada em quase todos os terreiros paraenses, que merecerá estudos posteriores.

Não há como quantificar os terreiros de Tambor de Mina existentes hoje na capital paraense dado o processo de organização política das religiões afro-brasileiras marcada pela descentralização. Não existe uma burocracia institucionalizada que registre e agregue a totalidade dos templos ${ }^{14}$ e nem os próprios terreiros ao iniciarem seus filhos armazenam informações formais sobre as "sucursais". Para entender essa lógica se faz necessário considerar que a base teológica e organizacional das religiões afro-brasileiras é marcada pela característica da oralidade e do que Weber (1999) chama de poder tradicional ou até, carismático.

A cosmologia dos terreiros de Mina possui traços estruturais semelhantes, mas sofrem variações consideráveis. Como qualquer religião que se forme a partir dos valores civilizatórios africanos, trata-se de uma sociedade de corte (ELIAS, 2001) haja vista que os deuses africanos e demais senhores de toalha são ancestrais divinizados e representações das forças da natureza. Sua teologia se constrói " da boca para o ouvido", com ênfase na transmissão pedagógica baseada na experiência e no poder da palavra. Seus deuses são adorados através de cantos e danças acompanhados por instrumentos musicais com ênfase no tambor. Essas são, no entanto, características gerais de todas as matrizes religiosas afro-brasileiras.

Os primeiros estudos sobre tambor de mina no Pará datam da década de 60. O casal de americanos, Seth e Ruth Leacock publicaram nos Estados Unidos, o livro Spirits of the Deep (1972) o resultado de uma observação efetiva, fruto do acompanhamento minucioso de diversas casas de culto, que perdurou sete meses - estendidos durante os anos de 1962 e 1963 e dois meses de retorno no ano de 1965 (LUCA, 2010).

Aos cultos tradicionais aqui encontrados, os Leacock chamaram de batuque, que para eles não eram uma degeneração do candomblé ou uma cópia de outras tradições religiosas. Trata-se, sim de uma religião muito própria, misturada na sua origem, porém um sistema independente caracterizado pela combinação de crenças yorubanas, daomeanas, indígenas com o catolicismo popular e o folclore ibérico (LUCA, 2010).

A principal contribuição desse casal de americanos foi, sem sombra de dúvida, a análise do panteão desta religião, descrito por eles como composto por um conjunto numeroso de entidades que possuem origens diversas, permeado pelo sincretismo afro-católico - que não podia ser descrito simplesmente como uma confusão. Nesta obra encontro a classificação detalhada de cada categoria, dentre as quais dou destaque aos

\footnotetext{
${ }^{14}$ No Pará existem várias instituições que agregam afro-religiosos. A mais antiga delas é a Federação Espírita, Umbandista e dos Cultos Afro-Brasileiros do Estado do Pará (FEUCABEP), fundada em 1964, no contexto da ditadura Militar. Sua função era conferir alvará de funcionamento para os templos religiosos que não eram agraciados com a liberdade de culto instituída apenas em 1988 com a promulgação da constituição federal. Outra tarefa da FEUCABEP era normatizar e controlar os cultos.
} 


\section{Uma experiência cruzada pelas águas do Pará:}

A família de Turquia no tambor de Mina

encantados - peculiares do eixo Maranhão - Pará - que se dividem em dois grandes grupos hierárquicos quais sejam: senhores e caboclos (LUCA, 2010). Eles são os primeiros a registrar também a presença de uma família de turcos no panteão religioso precedendo inclusive os pesquisadores maranhenses.

Esse panteão próprio é a grande característica litúrgica do Tambor de Mina ${ }^{15}$. As entidades são organizadas de forma hierárquica num sistema de Alto X Baixo (LUCA, 2010). No ápice encontram-se os senhores e na base os cabocos. Tais categorias de divindades e entidades organizam-se em família que agregam as lideranças e seus súditos. Essas famílias dialogam e circulam entre si e até se integram através de um processo migratório entre as mesmas.

Pode-se dizer, sem medo de errar, que se existe um elemento comum a todas as casas, é a presença das mesmas categorias de entidades (LUCA, 2010). Anaíza Vergolino afirma que em se tratando da mina no Pará "tanto se cultua os orixás nagôs (...) quanto aos voduns jejes que podem corresponder aos orixás nagôs (...).” (VERGOLINO, 2003: 22).

Segundo Luca (2010), o panteão se divide em duas macrocategorias que são as divindades e os encantados.

As divindades são tanto os orixás quanto os voduns (LEACOCK, 1972) que, ou representam as forças da natureza, ou são ancestrais negros (...) São eles as entidades máximas no que tange a hierarquia do panteão. Por isso são comumente referidos pela expressão: os brancos, sugerindo que este elemento tenha sido submetido a um processo de branqueamento. Essas entidades pertencem à categorias de "senhores", estabelecida pelo casal Leacock no livro Spirits of the Deep" (1972). (...) Os encantados são, por sua vez, personagens não africanos (FERRETTI, M, 2000) que pertencem a diversas nacionalidades, são europeus, turcos, índios, brasileiros, etc. Sua característica maior é a não morte (FERRTTI, M 2000; VERGOLINO, 2003). A maioria dos encantados é descrita como seres (pessoas, bichos) que tiveram vida, mas que não passaram pela experiência da morte. Saíram desse mundo de forma fantástica (TODOROVI, 2003) e passaram a habitar as encantarias que se localizam em lugares geográficos específicos, como matas, rios, praias, formações rochosas etc... (LUCA, 2010: pg 53).

Esses encantados podem pertencer ao alto status e serem descritos como nobres ou ao baixo status e serem descritos como cabocos. Eles pertencem a diversas famílias dentre elas as mais conhecidas são: as famílias de Turquia, Bandeira, Codó, Jurema, Surrupira etc. Cada família possui uma estrutura hierárquica definida com uma liderança, seus filhos e agregados. Trata-se de famílias extensas que invariavelmente possuem ligação com um orixá ou vodum.

Este artigo dedica-se a analisar uma família específica do Tambor de Mina conhecida como Família da Turquia, a mais popular cultuada em terras do eixo norte cultural composto pelo Estados do Maranhão, Pará, Amazonas, Amapá e etc... Esta Família forma-se a partir de um imaginário construído em torno da mitologema da água - mar (ELIADE, 1998) e pela negação do ethos da cristandade. Muitas são as narrativas contadas acerca dessa mitologia e para tanto divagaremos entre aquelas construídas por "mineiros" maranhenses e paraenses.

\footnotetext{
${ }^{15}$ Embora todos os terreiros de Mina cultuem as mesmas famílias e as mesmas categorias de entidades há variações significativas na organização e na mitologia contada sobre as mesmas.
} 


\section{Uma experiência cruzada pelas águas do Pará: \\ A família de Turquia no tambor de Mina}

\section{OS TURCOS NA MINA MARANHENSE}

A pesquisadora de referência nos estudos das famílias de cabocos e mais especificamente dos turcos no Tambor de Mina Maranhense é a professor Doutora Mundicarmo Ferretti. Dois são os artigos produzidos por ela com objetivo de analisar o tema. O primeiro denomina-se "Rei da Turquia, o Ferrabrás de Alexandria? A Importância de Um Livro na Mitologia do Tambor de Mina" (1989) foi publicado em uma coletânea de textos denominada "Meu Sinal Está do Teu Corpo" organizada pelo professor Carlos Eugênio Marcondes de Moura.

O segundo denomina-se "Repensando o Turco no Tambor de Mina", fruto de uma conferência realizada em 1986 no Congresso Internacional sobre Escravidão realizado na USP. Há a referência à Turquia também em seu livro "Desceu na Guma" (1993), onde a autora analisa os cabocos a partir do terreiro de Fanth Ashanth e em outras obras na mesma autora.

A autora reconhece a importância do culto a fidalguia e aos caboclos cultuados em todos os terreiros do Maranhão e do Pará, exceto no famoso Querebetã de Zomadonu. A família de Turquia teve sua origem no famoso Terreiro da Turquia, fundado na segunda metade do século XIX por Anástácia Lúcia dos Santos. A sacerdotisa era natural da cidade de Codó que migrou para São Luís, aos treze anos de idade. Esta senhora entrou em transe com rei da Turquia que era conhecido como Almirante Balão ou como seu Filho, Ferrabrás de Alexandria. A construção mitológica sobre esta entidade vai beber no romance Carlos Magno e os Doze Pares de França que a sacerdotisa teria ganhado de um Turco radicado em território maranhense e guardado dentro de um baú.

Sua casa foi fundada na Nação Taipa e chegou a agregar mais de vinte filhos de santo. Reconhecida pela comunidade afro-brasileira como "o berço da linha de turco ou nação taipa que pertencem aos encantados também conhecidos como mouros" (FERRETTI, 1986:60). A linha de taipa, também chamada de beta, se caracteriza por ser um "nagô islamizado" (FERRETTI, 1086: 60) que congrega os turcos mauritanos cuja principal característica é a nobreza e a guerra. Essa nação também se fazia frequente no extinto Terreiro do Egito, berço de Rei da Bandeira, irmão de seu Turquia e na Casa de Nagô, onde as entidades taipa eram consideradas Nagôs (FERRETTI, 1986).

Esses negros taipa foram etnografados por Raimundo Nina Rodrigues que os caracterizou como negros relacionados com os Hauça. O pai de santo de mãe Anastácia (e de mãe Doca,), o negro Manoel Teu Santo era um "tapa nagoizado que por pertencer a uma nação islamizada, teria recebido em sua casa uma entidade conhecida como Rei dos Turcos (FERRETTI, 1986: 61)".

Dada a origem codoense de mãe Anastácia, é forte o vínculo do terreiro da Turquia com o Codó. Sua família transitava nos terreiros de São Luís e sua mãe chegou a abrir, na capital, um terreiro que cultuava a "linha da mata" (FERRETTI, 1986).

Mãe Anastácia, vindo aos 13 anos para São Luís, morou por algum tempo, na Casa das Minas (que (...) é muito ligada ao povo Codó), tornando-se muito amiga de Mãe Andreza. 


\section{Uma experiência cruzada pelas águas do Pará: \\ A família de Turquia no tambor de Mina}

Frequentando o terreiro de Manoel Teu Santo Bolou com Nanã Burucu (cultuada na casa de jeje como entidade Nagô)recebendo depois Pedrinho (orixá ou fidalgo) e Rei da Turquia (na linha de Caboclo). Como este vinha em sua cabeça mais frequentemente, foi para ele que abriu terreiro em 1889. Segundo Euclides, Anastácia dirigiu a Turquia durante 83 anos, preparando muitos filhos-de-santo e implantando várias casas de mina no Maranhão e no Pará” (FERRETTI, 1986: 62).

A sacerdotisa faleceu com mais de cem anos e a deixou o terreiro da Turquia sob comando de pai Euclides, fundador do terreiro de Fanth Ashanti que incorporava com três encantados turcos, dentre eles seu Jaguarema. O legado de mãe Anastácia pode ser percebido pela difusão do culto às entidades turcas em quase todos os terreiros de mina e de umbanda no eixo Maranhão-Pará. Pode-se dizer que mãe Anastácia foi para o Tambor de Mina, o que o apóstolo Paulo representou para a Igreja Católica, a grande responsável pelo seu processo de expansão e radicação não só no estado natal, mas também em diversos outros Estados,

Mundicarmo Ferretti em seu livro "Desceu na Guma” os classifica como gentilheiros e os descreve como "fidalgos, não confundidos com os orixás, as vezes também confundidos com os caboclos (...) que não pertencem a nobreza europeia cristã " (FERRETTI, 2000; 74).

Seu chefe de croa era o próprio líder da família de Turquia, o que faz de seu terreiro a meca dos turcos no Brasil.

Segundo Mundicarmo Ferretti (1986):

Os turcos eram também conhecidos devido o romance Carlos Magno e os Doze Pares de França, muito procurado em São Luís na antiga livraria Ramos de Almeida pelo povo do interior do Estado, como nos assegurou o escritor José Jansen, filho do proprietário que trabalhou ali nos anos vin1' te. (...) (FERRETTI, 1986: 63).

A influência da memória mourisca se faz presente na religião e também no folclore maranhense e paraense. Professora Mundicarmo remete às danças dramáticas registradas por Oneyda Alvarenga em 1948 como a chegança e nós apontamos a cavalhada, espécie de ressignificação das batalhas entre turcos e cristãos que até hoje praticadas em manifestações do catolicismo popular como a Marujada, realizada na região bragantina em municípios paraenses como Bragança, Tracuateua e Quatipuru.

Ferretti (1986) reitera que muitos personagens da literatura de Carlos Magno migraram para a mitologia mineira como o Almirante Balão - pensado como o próprio Rei da Turquia -,a princesa Floripes, referida como sua esposa ou como filha - , Ferrabrás - Filho do Almirante, que dá nome a uma das famílias da Turquia - e Burlante - conhecido por ser o comandante do Navio de Dom João que trouxe o rei, chefe da família, para o Brasil.

Os turcos são entidades conhecidas por seu caráter de nobreza apresentam insígnias demarcadoras de status como toalhas bordadas em richilhieu e bengalas. Organizam-se em famílias patriarcais cuja liderança é invariavelmente masculina. Por vezes é possível conhecer o líder fundador da família mas muito raramente se tem acesso ao nome da esposa o que se explica, segundo Ferreti (1986) "geralmente não se conhece ou não 


\section{Uma experiência cruzada pelas águas do Pará: \\ A família de Turquia no tambor de Mina}

se pode falar nas mães dos caboclos. É possível que esse tabu emcubra sua origem popular ou bastarda pois, geralmente apregoa-se a nobreza de seus pais (FERRETTI, 1996:58).

Como já foi mencionado anteriormente, Rei da Turquia é a grande liderança da família que recebe seu nome. A Turquia no Estado do Maranhão, é organizada em três sub - famílias: Ferrabrás (a legítima), Borgonha e Ramos, vinculada aos franceses e Portugueses. Apesar de turco, este nobre estabelece vinculo de parentesco com Dom Luís, rei de França e Dom João, de quem é primo (FERRETTI, 1986). Sobre as esposas, sabe-se que são diversas, uma vez que os turcos se caracterizam pela poligamia, no entanto só se conhece o nome de uma delas: Maria Leonor. Essa categoria de entidades conhecidas como fidalgas, na qual Rei da Turquia está inserido, confunde-se muitas vezes com os orixás iorubanos, ou como os voduns jejes.

Há referência a inimizade entre essas entidades e o cristianismo, apesar da tentativa de mãe Anastácia em cristianizar os turcos dada sua afeição pelo catolicismo e pela devoção santoral. Mundicarmo Ferretti, nos relata:

"A inimizade entre mouros e cristãos no discurso dos encantados e das pessoas ligadas à Mina Maranhense vêm também de longas datas. Segundo Euclides (com Tabajara), a luta começou quando os cristãos da Europa, não aceitaram o almirante Balão como rei das terras de Mouro, por ser turco, e os turcos não quiseram se submeter ao rei português (Dom Manoel ou Dom João), apesar de seu Turquia ser primo de Dom Luís e de Dom João. A batalha tornou-se mais intensa quando uma irmã de Rei da Turquia (Floripes?) ligou-se a um estrangeiro e houve participação de muitos nobres a quem o romance não se refere como Dom Francisco e Dom Felipe (seriam cristãos que passaram para o lado dos turcos pois na casa de Euclides, há uma toada de cura onde o primeiro se diz filho de rei da Turquia)" (FERRETTI, 1986:65).

Apesar de pagãos os turcos desenvolvem relação de respeito com o cristianismo. Na mitologia contada em São Luís, muitos deles foram até convertidos. "Anastácia era católica e os Voduns do Maranhão são devotos dos Santos. A Turquia sempre procurou fazer com que os mouros, que chegaram ali como encantados, se tornassem cristãos" (FERRETTI, 1986: 65).

Outra diferença entre a história e a mitologia diz respeito a vitória das batalhas. Se as cruzadas, em sua maioria, foram vencidas pelos cristãos que conseguiram cristianizar os chamados "infiéis", no imaginário do tambor de mina, os turcos são guerreiros vencedores. Não são vistos como maus ou derrotados, mas povos que procuram ajudar seus inimigos e agregar os filhos dos aliados (em sinal de gratidão) e dos vencidos (como sinal de paz) em seus domínios de encantaria (FERRETTI, 1986).

Muitos são os caboclos que descendem direta ou indiretamente dessa família. A família da Turquia no Maranhão é composta por mais de 200 encantados. Alguns deles pertencem a outras famílias e se aproximam da Turquia por afinidade ou por doação. Consta que o próprio Caboclo Nobre foi dado ao rei por Pedro Angaço (FERRETTI, 1986).

Geralmente eles incorporam nos filhos-de santo em dias ordinários para trabalhar (desfazendo feitiços, realizando curas, etc) e nos dias festivos para brincar, beber, fumar, cantar, dançar e encontrar amigos. Caracterizam-se por cores específicas, a da família de Turquia é verde, amarelo e vermelho. São elas que 


\section{Uma experiência cruzada pelas águas do Pará: \\ A família de Turquia no tambor de Mina}

prevalecem nas vestes, guias e decorações das festividades de turco. Podem apresentar-se de forma séria ou brincalhona, com aparência de idosos ou jovens.

Assim como os nobres portugueses, os turcos possuem forte ligação com as águas salgadas (FERRETTI, 1997:6) o que é expresso no movimento das danças, nas doutrinas entoadas como apresentação dos encantados e na mitologia narrada.

Não há como negar a influência religiosa que o Maranhão exerce sobre a religiosidade paraense. A origem do tambor de mina no Pará deita raízes d Maranhão (VERGOLINO, 2000), raízes essas que nunca foram podadas dado o contato estabelecido entre sacerdotes dos dois estados seja por origem iniciática, seja por visitação em busca de "catar folha" 16 , seja ainda pelas relações de afeto que nascem dessas redes familiares espirituais. Todavia é preciso ressaltar que esta influência não faz resultar cultos e mitologias idênticas nos terreiros das duas capitais.

Se há similaridade entre a narrativa exposta acima e a que será relatada no tópico subsequente, há também muitas disparidades oriundas das peculiaridades identitárias de cada estado. Uma das diferenças diz respeito a ênfase dada ao Livro Carlos Magno e os Doze Pares de França. Se em São Luís ele é fartamente lido e referido, podemos afirmar que em Belém ele é quase desconhecido. Nunca o vimos na biblioteca de nenhum terreiro ou sacerdote e a referência aos personagens presente no livro chegam ao Pará pela oralidade e pela performance ritual que também funciona como narrativa.

Nossa explicação para essa discrepância está pautada na diferença histórica entre os dois Estados uma vez que na memória oficial do Pará não consta uma invasão francesa. O vínculo identitário com a França não é um marco da nossa identidade e em função disso, uma epopeia ligada a história desse país não soa como auto pertencimento.

Feita a apresentação dos Turcos no Maranhão, partimos para relatar a versão paraense do mito que possui mais relação com sebastianismo e com os personagens próprios da mitologia amazônica (como os botos) do que com a história de Carlos Magno. Atravessemos a fronteira e contemos o mito Turco na Amazônia.

\section{OS TURCOS NAVEGAM PARA AS ÁGUAS DO PARÁ}

A versão aqui apresentada pode sofrer variação entre os demais terreiros de mina existentes em território paraense em função da característica do mito que é, invariavelmente, uma narrativa viva e atualizada pela história. Os turcos são considerados como pertencendo a uma família híbrida e agregadora que acolhe todas as categorias de entidades e membros de todas as outras famílias como Codó, Bandeira, Ciganos, Jurema, etc. Organizam-se a partir de uma hierarquia interna que se constrói em cima de dois elementos simbólicos básicos: a realeza e a estrutura de exército.

Uma característica dessa família é a ambiguidade. As entidades podem transitar entre as categorias hierárquicas da família ou se apresentar ora como senhores e ora cabocos a exemplo de Dona Mariana, têm

\footnotetext{
${ }^{16}$ A expressão catar folha é utilizada pela comunidade afro-religiosa como sinônimo de recolher conhecimento. 


\section{Uma experiência cruzada pelas águas do Pará: \\ A família de Turquia no tambor de Mina}

várias matizes, podendo "baixar" como princesa, caboca, ou animal assumindo a forma de arara se ligada a chamada linha de cura, matriz religiosa advinda da Pajelança cabocla que influencia o Tambor de Mina através de um processo sincrético.

A Turquia é composta de nobres mestiços, descritos, por alguns afro-religiosos paraenses, como não brancos e não cristãos. O que remete, assim como no Maranhão, a origem histórica dos mouros, personagens das chamadas Cruzadas, lutas estabelecidas entre a realeza católica ibérica e os chamados povos "pagãos" do norte da África durante os séculos XXI e XV.

$\mathrm{Na}$ maioria das vezes vestem-se com roupas finas e luxuosas confeccionadas de tecidos brilhosos e richelieu colorido. Todavia, por serem personagens ambíguos, podem também trajar roupas de florão que os aproximam dos juremeiros e codoenses.

Outro elemento que merece destaque é que, além de mestiços, esses nobres são descritos em Belém, invariavelmente como não cristãos. Quanto a origem religiosa, são classificados como mulçumanos ou judeus. A negação do cristianismo é um elemento importante na narrativa mitológica, no entando se faz necessário explicar que essa negação diz respeito a estrutura burocrática do catolicismo e sobretudo ao batismo podendo, esta família, agregar a devoção ou festejo aos santos católicos, típicos do que se convencionou chamar de catolicismo popular.

A Turquia referida no terreiro é uma espécie de cidade encantada construída a partir de uma estrutura social hierárquica e bélica o que faz o ouvinte se perguntar se não se trata de um exército. O sacerdote narrador desta mitologia se refere a ela como um império para destacar seu caráter de nobreza.

É como se fosse uma nação que tem seus governantes, seus ministros, seus governadores. Eles (os Turcos) vieram no mundo para servir, digamos assim... Não travam uma guerra contra os inocentes, é uma guerra contra inimigos espirituais. Entendeu? Só que como existe guerreiro (...) o guerreiro recebe uma ordem ele vai e faz. A função é a proteção do mundo. Cada casa, cada terreiro é um mundo. Eles (os Turcos) são as autoridades. O auto escalão chefia de cima, eles irradiam as firmezas das pessoas, do que tem dentro da casa. Eles irradiam luz para aquele lugar. Mas deles nascem também pontos estratégicos de defesa, de guerra contra inimigo. Entendeu? Para defender o homem aqui. A Turquia é uma cidade paralela. É uma cidade de encantaria, invisível. É uma cidade de dimensão diferente (Pai Mosaniel Reis Costa, sacerdote do Tambor de Mina).

Essa hierarquia, que também se configura no sentido alto $\mathrm{x}$ baixo, tem no seu ápice a figura do que o sacerdote chama de "trindade" real formada por três entidades as quais o mesmo classifica como "orixás". No alto escalão hierárquico da cidade sagrada da Turquia temos os deuses negros Xangô (yorubano) e Vó Missã (Nanã - Jeje) e o orixá abrasileirado ${ }^{17}$; Rei da Turquia. A essa trindade cabe a "governança" da Turquia, imposição de normas e gerenciamento de sua organização. Essas três entidades faziam parte do "carrego ${ }^{18 "}$ recebido por mãe Anastácia, o que nos faz sugerir que O Terreiro da Turquia seria a versão terrena de uma cidade sagrada homônima.

\footnotetext{
${ }^{17}$ Denominação nativa. O narrador classifica Rei da Turquia como um orixá abrasileirado.

${ }^{18}$ Conjuntos de entidades recebidas por uma pessoa.
} 


\section{Uma experiência cruzada pelas águas do Pará: \\ A família de Turquia no tambor de Mina}

Abaixo dessa trindade existe uma realeza intermediária cuja responsabilidade é estabelecer a comunicação entre a suprema corte e o baixo escalão. São entidades que representam os quatro elementos da natureza (terra, água, fogo e ar) e que são responsáveis pela transmissão das ordens de cima para baixo. Nesta categoria encontram-se os reis, barões, boçus e outros nobres. Dentre eles destaca-se Dom João Rei de Mina, Dom João de Embarabaia, Marquês de Pombal (Indaê), Barão de Goré, Barão de Oeiras, Boçu Jandiá, Boçu Jara, Boçu Xadatã, Boçu Kó ${ }^{19}$, Caboco Sentinela , Princesa Floripes, dona Maria Leonor, princesa Doro, Joana D’ Arc.

Pertencem também a essa categoria alguns orixás e voduns que "arreiam ${ }^{20 "}$ na Turquia se misturando aos nobres a exemplo de Mãe Maria que seria uma Oxum. Além dela apontamos Xapanã, Averequete, Acossi e Iemanjá que são "Preparados dentro da Turquia” (Pai Mosaniel Reis Costa, Sacerdote do Tambor de Mina). Apesar deste grupo se posicionar abaixo da "trindade patronal da Turquia", quando esses nobres descem em Guma $^{21}$ incorporando seus filhos e filhas-de-santo, eles dialogam e sentam na mesma mesa pois fazem parte de uma cúpula real e possuem status de vodum.

Floripes era considerada a filha preferida de Rei da Turquia mas traiu sua confiança, se atrelando aos cristãos e levantando falso testemunho sobre o pai por pura ambição. De acordo com a narrativa princesa Floripes teria acusado o pai de assédio e por isso foi expurgada de sua encantaria passando a viver numa zona marginal onde nem todos os caboclos transitam, espécie de reino segregado dentro da Turquia. Floripes tem diversas filhas que também possuem nomes de flor como Flor de Aurora, Flor da Barra, Flor das Nuvens, Flor Divina e Flor do Mar. Elas foram afastadas junto com a mãe mas possuem permissão de transitar vez ou outra pelos domínios do avô.

Consta que, com a traição de Floripes, quem ocupou seu lugar de preferida do rei foi Cabocla Mariana, cujo nome lhe foi dado em função da devoção à Maria Santíssima. Esta caboca é originária da realeza espanhola mas foi expulsa desta corte Ibérica por seu comportamento de mulher que foge aos padrões sociais, rindo desmedidamente, falando alto e dançando com suas castanholas. Sua autonomia desagradou a sociedade patricarcal da época fazendo com que os espanhóis a jogassem ao mar. Ela teria sido salva por um dos tubarões $^{22}$ pertencentes a corte lusitana de Rei Sebastião que não só a recolheu como a cuidou. Rei Sebastião, por seu caráter de liderança política, costumava visitar os domínios de encantaria de Rei da Turquia e numa dessas viagens levou Mariana que se agradou do Rei.

Por sua vez, rei da Turquia, que havia acabado de perder sua filha, agregou Mariana enquanto tal e esta passou a ser a "menina dos olhos" do turco, o que lhe rendeu o privilégio de trafegar por entre as categorias

\footnotetext{
${ }^{19}$ Segundo a Narrativa de Pai Mosaniel Reis Costa a Família de Boçu é egressa da casa de Jeje e se agregou a Turquia.

${ }^{20}$ Sinônimo de baixar, entrar em transe ou apresentar-se de forma mediúnica.

${ }^{21}$ Expressão utilizada no sentido de entrar em transe.

${ }^{22} \mathrm{Na}$ mitologia contada sobre rei Sebastião no Terreiro de Nagô Nossa Senhora da Conceição, o Rei Dom Sebastião não possui tanta correlação com touro mas com um casal de Tubarões, chamados Pelisan. São considerados "ordenança” do rei, responsáveis por abrir caminhos para que sua corte atravesse do Maranhão para o Pará, desembarcando em diversas zonas de encantaria como São João de Pirabas. Segundo o sacerdote Mosaniel Reis Costa, as pessoas que moravam no interior do Pará, viam esses tubarões, boiar na praia, em dias de lua cheia, trazendo a corte do rei.
} 


\section{Uma experiência cruzada pelas águas do Pará: \\ A família de Turquia no tambor de Mina}

sociais da Turquia, se apresentando de diversas formas. Assume o papel de nobreza, quando "está na linha" de princesa, de passeadora, quando cabocla e de feiticeira, quando vêm na categoria de arara cantadeira. "Dona Mariana ela passeia em todos os mundos. Ela vai como defesa quando ela tá na mata, como arara e quando ela tá no mar ela some nas maiores cúpulas da Turquia” (Pai Mosaniel Reis Costa, Sacerdote do Tambor de Mina).

A afetividade de rei da Turquia rendeu tanta popularidade a cabocla Mariana que em todas as casas de culto do estado do Pará existe pelo menos um (a) médium que recebe a encantada. Ela acabou ficando como a maior representante da família de turco e do próprio rei que pouco se apresenta pela experiência do transe. Foi dona Mariana, e o amor semeado pela mesma no coração do rei turco, que permitiu a aceitação à devoção santoral católica dentro dos domínios da encantaria pagã.

Como terceiro escalão da hierarquia estão os turcos guerreiros caracterizados por serem desbravadores de áreas de encantaria, conquistando e tirando espíritos ruins destes espaços. Nesta categoria encontram-se caboco Guerreiro, Seu Zeferino, João Navalheiro e Caboclo Velho que originalmente pertence a família de Surrupira e se agrega a Turquia. Outra versão da Narrativa diz que Caboclo Velho é o nome recebido por Rei da Turquia quando o mesmo adentra em terras amazônicas. Como desbravadores que são sua função é conquistar zonas de encantaria e por isso esta entidade muda de nome a cada território adentrado. Consta na narrativa que Caboclo Velho ao entrar no Amazonas recebe o nome de Japetequara.

Abaixo da categoria de guerreiros está a Fidalguia também conhecida como responsáveis "pelo trabalho social do império" que seria a "obrigação ${ }^{23}$ " e a "baia ${ }^{24 "}$. São eles que atuam nas festividades e descem nos médiuns como passeadores ${ }^{25}$ e brincantes durantes os tambores. A principal de toda essa categoria é a cabocla Mariana, a turca mais conhecida e mais recebida do tambor de mina.

Além de dona Mariana destaca-se nessa categoria Caboclo Mariano ${ }^{26}$, Seu Laguará, Seu Tabajara, Seu Urubatã de Jesus, Caboco Rochedo, Rosarinho, Tabajara, Pindá, Cachoeirinha, Camaroeiro ${ }^{27}$, Joãozinho ${ }^{28}$, Miguelzinho ${ }^{29}$, Pombo do $\mathrm{Ar}^{30}$, Pelegrino ${ }^{31}$, Ubirajara ${ }^{32}$, Ubirata ${ }^{33}$, Ubiraci $^{34}$, Turco Fera, Caboco Roxo, Aquiritaua e dona Jarina, a filha de Rei Sebastião entregue a rei da Turquia para compor sua família extensa.

\footnotetext{
${ }^{23}$ As oferendas realizadas

${ }^{24}$ A dança, a festa.

${ }^{25}$ Cabocos que incorporam nos médiuns em momentos festivos para brincar, dançar, beber, conversar. São opostos aos chamados trabalhadores que descem para realizar serviços diversos. Há casos que o mesmo caboco pode assumir os dois papéis.

${ }^{26}$ Irmão de dona Mariana

${ }^{27}$ Oriundo da Família do Codó mas passeia pela Turquia.

${ }^{28}$ Filho de Dom João.

${ }^{29}$ Filho de dom Miguel e membro de sua Família mas que transita na família de Turquia.

${ }^{30}$ Filho de Marquês de Pombal

${ }^{31}$ Filho de Marquês de Pombal

${ }^{32}$ Filho de seu Tabajara

${ }^{33}$ Filho de seu Tabajara

${ }^{34}$ Filho de seu Tabajara
} 


\section{Uma experiência cruzada pelas águas do Pará: \\ A família de Turquia no tambor de Mina}

A família de Marinheiros que mora na Turquia também se agrega a essa categoria. Entre eles destacamos Marinheiro Xoroé (caboclo Água Verde), Marinheiro Fernandinho, Seu Júlio Galego (conhecido como Galeguinho). "Os Marinheiros, eles fazem parte do clã do social só que eles obedecem um comandante chamado Comandante João de Lima. Esses marujos todos obedecem a ele" (Pai Mosaniel Reis Costa, Sacerdote do Tambor de Mina).

Outros caboclos que se agregaram ao "social da Turquia" foram os ciganos a destaque de caboca Ciganinha Nina, Cigano Burlante, Cigana Nochinina (Bela Cigana), Inambé, Ninamur, Minrinha ${ }^{35}$, Micuim ${ }^{36}$ Jatorana (também conhecido como Jatuarana ou Caboco Guido), Cigano Mucambo, Tinicaca ${ }^{37}$. Esse grupo, denominado de Ciganos Ganjãos, formado por povos nômades de origem espanhola, veio morar na família de Turquia sob a chefia de rei Acamador e muitos deles também transitam pelas matas do Codó.

A categoria dos Juremeiros também se aproximaram da família de Turquia. Caboclos índios passeiam na Turquia fazendo parte de uma coluna do império denominado de os "Alencar". Trata-se de uma família de índios que passaram a residir na Turquia, entre eles destaca-se caboco Pena Verde, Caboco da Sete Flexa, Caboco Pena dos Astros, Caboco Roxedo, Abitaquara, Caboco da Pena Dourada, Caboca Jurema e Caboca Iracema. Baiano Grande e Xica Baiana que pertencem originalmente a família da Bahia responsáveis por tomar conta os touros de Rei Sebastião cruzam as fronteiras da Turquia.

Na base da hierarquia da família da Turquia estão os chamados "cabocos de impactos e de ação", conhecidos como "os feiticeiros da Turquia". Essa equipe é composta por Caboco Jaguarema, Jaguarão, Caboco Maroto, Seu Goiabeira, Seu Limoeiro, Caboquinho da Maioba, Menino de Tananga, Caboco Flecheiro, Caboco Gonçalo, Caboco Guapindaia, Guerreiro de Alexandria, Itaculumim, Joana Gunça ${ }^{38}$, Seu Folha Seca ${ }^{39}$, Jurassema, Menino da Lera, Mensageiro de Roma, Menino de Areia, Caboco Paraense, Pau Reverso (Também conhecido como Infinca o Pé) ${ }^{40}$, Tapindaré e outros.

A função desses cabocos é vencer demanda e desfazer feitiço o que lhes confere o título de "esquerda da Turquia". São entidades que conhecem a alta magia funcionam como sentinelas, fazendo a proteção do império de ataques e dos malefícios de adversários. Segundo o sacerdote "Essa classe aí todinha é a classes de defesa da Turquia, são os guardiões da Turquia" (Pai Mosaniel Reis Costa, Sacerdote do Tambor de Mina)

Uma das cabocas mais importantes entre os feiticeiros é dona Herundina, filha de Rei Camundá, o Rei Caranguejo, que foi entregue para criação de rei da Turquia. Dona Herundina,, por sua função estratégica, não recebe ordem da fidalguia dos passeadores, transitando entre as instâncias num diálogo direto com a alta cúpula do império. Ela também cruza os limites do alto X baixo para buscar as ordens de proteção diretamente com a trindade sagrada.

\footnotetext{
${ }^{35}$ Cigana Turca, criada na família de Légua.

${ }^{36}$ Irmão da Cigana Mirinha.

${ }^{37}$ Cigano que não pertence a corte espanhola mas têm origem egípcia.

${ }^{38}$ De acordo com a Narrativa esta entidade pertence a família de Codó mas migrou para Turquia, onde mora.

${ }^{39}$ Pertence a família de Bandeira mas se agregou a família de Turquia por simpatizar com o rei.

${ }^{40}$ Este Caboclo se apresenta a semelhança de um exu
} 


\section{Uma experiência cruzada pelas águas do Pará: \\ A família de Turquia no tambor de Mina}

Em função de sua característica de sentinela e proteção, os "feiticeiros da Turquia" essas entidades se assemelham aos exus ${ }^{41}$ da umbanda. Alguns deles podem inclusive se fazer presente ao término das festas de exu, quando os cabocos descem para "fazer a limpeza" o espaço do terreiro. Além desses turcos de esquerda, os codoenses também acessam os festejos dos catiços ${ }^{42}$. Cabe a eles ficar de prontidão nos arredores do terreiro garantindo a paz.

Vale lembrar que alguns dos terreiros mais antigos de Belém, não cultuam exus no formato de catiços, tal qual na Umbanda. Na casa de mãe Raimundinha (Terreiro da Cocada), não havia transe com exu. Ela cultuava essa categoria de entidade sob o nome de "Povo de Ganga". Atrás da porta da rua havia as "firmezas"43 dessas entidades que eram alimentadas, antes de cada ritual, por uma pessoa específica chamada de cambono, responsável por colocar cachaça no assentamento sacralizado como "segurança da porteira". Na ausência dos exus quem fazia a proteção dos terreiros eram entidades consideradas de esquerda e presente na maioria das famílias do panteão. Algumas casas eram protegidas pela família de surrupira ${ }^{44}$ ou de légua ${ }^{45}$, que atuava a semelhança dos exus.

Nesta organização a Turquia, da trindade a fidalguia, pode ser chamada de Direita da Turquia e os Feiticeiros de esquerda do império. Pela diversidade de entidades oriundas das mais diversas categorias e famílias pode-se perceber que:

"Rei da Turquia é um africano agregador. A postura dele é do senhor da Justiça, é de um Rei Nagô. Ele é um rei Nagô. (O Terreiro da Turquia) é chamado Nifé Orum. Nifé Orum quer dizer a junção entre o céu e a terra. Tudo junto.. O diretor da casa é Xangô e sob as ordens dele, estão os outros orixás. Por exemplo, os Boçus dentro da Turquia representam Oxossi, as famílias de Boçu, os Massaquenas, os cavalheiros Massaquenas. Enfim, é muita história, tem muita coisa linda na Turquia" (Pai Mosaniel Reis Costa, sacerdote do Tambor de Mina)

\footnotetext{
${ }^{41}$ Uma das entidades mais importantes dos cultos afro-brasileiros, não é cultuada na mina mais tradicional, tendo ingressado em seu panteão através do sincretismo. É o mensageiro entre os deuses e os homens. Suas funções são diversas, sem ele nada se faz dentro de uma casa-de-santo. É considerado o senhor dos caminhos. Foi sincretizado pelos cristãos com a figura do Diabo.

${ }^{42}$ Nome dado na casa para referir aos exus da umbanda que, por um processo sincrético, baixam em alguns terreiros de mina.

${ }^{43}$ Sinônimo de assentamento

${ }^{44}$ Os Surrupiras são descritos por Vergolino (2003) como "encantados locais, tendo sua encantaria ou morada na localidade de Arapixi, município de Chaves, Ilha do Marajó". As narrativas sobre essas entidades são imprecisas. Uns os descrevem de índios não "civilizados", outros como personagens

zoomórficos muito peludos. O fato é que todos concordam com os hábitos selvagens que os surrupiras têm, de se embrenhar no meio do mato, se abraçar com as árvores de tucumã, ou até dormir em cama de espinhos.

${ }^{45}$ Dá-se o nome de Légua ouFamília do Codó, ou Família da Mata ao grupo de entidades advinda da cidade Maranhense do Codó, são considerados cambinda e chefiados por Pedro Angaço e Seu Légua. Descritos a partir da imagem do negro que vigora no Pensamento Social Brasileiro do século XIX. Trata-se do "preto, preto, preto de cabelo ruim" que realiza trabalhos domésticos dentro do terreiro Possui forte ligação com o gado. Suas doutrinas falam da sela, do ato de laçar boi e outras atividades desse gênero. Suas vestes são confeccionadas com tecido colorido, chamado de florão. Antigamente usavam exclusivamente roupas de tecido de chita, hoje podem vestir panos mais finos, mas invariavelmente estampados. É comum utilizarem chapéu de couro estilo boiadeiro ou cangaceiro. As cabocas mulheres, dessa família, podem ornamentar os chapéus com fitas coloridas.
} 


\section{Uma experiência cruzada pelas águas do Pará: \\ A família de Turquia no tambor de Mina}

Rei da Turquia em Belém não é associado ao Ferrabráz de Alexandria e nem ao Almirante Balão. O Romance "A História de Carlos Magno e os Doze Pares de França”, conforme já foi mencionado, não impacta, de forma direta, na construção da mitologia sobre a família de Turquia no estado do Pará, em função pela inexistência de vínculo colonial entre este estado e a França. A eventual semelhança narrativa certamente advém do vínculo iniciático estabelecido entre sacerdotes paraenses e maranhenses. Atrevemo-nos a afirmar que a correlação chega pela oralidade distante. O sacerdote narrador desta mitologia é claro em afirmar "Olha eu não acredito totalmente nessa versão do livro. Aqui é diferente. Nem tudo isso dos Doze Pares de França (nós seguimos)... Tem umas coisas que são reais e outras foram misturadas" (Pai Mosaniel Reis Costa, Sacerdote do Tambor de Mina).

O que é considerado real no livro é o fato do rei da Turquia ser um personagem das cruzadas. Repetese frequentemente a frase que "ele não é cristão" ou "eu não sou cristão", quando o entrevistado é a própria entidade turca. Para pai Musa, não existe judeu cristianizado. Embora muitos dos turcos possuam ligação com os santos o que nos leva a crer que o repúdio direciona-se ao catolicismo oficial e à instituição da Igreja.

Seu Jaguarema, turco chefe do Terreiro de Nagô Nossa Senhora da Conceição, em sua festividade, levantava um mastro em devoção ao Menino Jesus de Praga. A devoção teve início em função de uma cura espiritual que ele fez a uma criança, quando o sacerdote morava em Manaus. Uma família chegou a sua casa trazendo uma criança bastante debilitada aos braços e o santo se apresentou ensinando o caboco turco a realizar a cura dessa criança. Uma vez sadia a própria criança pediu ao pai que comprasse a imagem do Menino Jesus de Praga para presentear o sacerdote, junto com uma fileira de peixe Jaraqui. Por gratidão ele passou a cultuar a imagem nos dias de sua festa a 29 de novembro.

\footnotetext{
"Eles (os Turcos) acreditam em um Deus, que não é um Deus aprisionado. (...) A Igreja católica da época não era total liberdade. Ela te restringia em umas certas coisas e na compreensão de rei da Turquia, Deus não quer nada que prenda. (...) Então era um combate muito grande. A própria Igreja da época perseguia muito. Só que Rei da Turquia (...) era um catedrático porque ele conhecia o que tinha dentro da Igreja. Ele era um conhecedor da Igreja. Ele era um crítico da Igreja. Ele critica o falso idealismo da igreja da época, a submissão, o dar tudo de si para Igreja, o construir riquezas. No Tambor de Mina não se aceita isso. Rei da Turquia era contra tudo isso. Ele era contra as injustiças. (...) Tem muito osso (nessa parte da história da) Igreja Católica e é isso que os encantados da Turquia não aceitam. E outra... Seu Rei da Turquia, (...) tem uma formação judaica" (Pai Mosaniel Reis Costa, Sacerdote do Tambor de Mina).
}

Ora os turcos são associados ao islã, ora são chamados de judeus o que nos faz intuir uma ideia de agregação das "religiosidades marginais" no contexto colonizador. Segundo a narrativa, a dança de turco performatiza o transe sufi ${ }^{46}$ uma vez que "eles marcam o mundo em roda” (Pai Mosaniel Reis Costa, Sacerdote do Tambor de Mina). Os encantados da Turquia possuem vínculo com a liberdade religiosa e de atitude "por isso eles bebem e fumam" (Pai Mosaniel Reis Costa, Sacerdote do Tambor de Mina).

\footnotetext{
${ }^{46}$ Parte mística do islã que se utiliza da dança e da música para estabelecer comunhão com a divindade.
} 


\section{Uma experiência cruzada pelas águas do Pará: \\ A família de Turquia no tambor de Mina}

Para o narrador, o tambor de Mina, conhecido como Mina Nagô obedece a um rei, o rei Xangô e quando mãe Anastácia fundou o Terreiro da Turquia, o rei turco veio representar o orixá maior da nação. "Não deixa de não ser Xangô" (Pai Mosaniel Reis Costa) que se abrasileirou em território nacional. Considerado uma entidade muito justa que "faz qualquer coisa para aplicar a justiça e defender os perseguidos" (Pai Mosaniel Reis Costa, sacerdote do Tambor de Mina).

As famílias do tambor de mina, por seu caráter de sociedade de império, estabelecem relações diplomáticas entre si. Rei da Turquia e Rei Sebastião são considerados irmãos de fidalguia. Esses chefes de famílias estabelecem relações diplomáticas que podem se caracterizar pela visitação ou pelo transito de entidades entre as mesmas. A exceção é marcada pelo Rei da Bandeira que por ser uma por entidades cristianizada e batizada não é muito bem vista pelos turcos.

A afirmação da identidade nacional brasileira e regional amazônica se faz presente nos nomes dos turcos acima citados. Um dos elementos demarcadores da identidade nacional e amazônica é a figura do índio, pensado como mito de origem da nação. Os turcos, apesar de estrangeiros, ao radicarem-se em território nacional assumem nomes indígenas, o que faz com que um religioso do Tambor de Mina, denominado Pai Tayandô (falecido) no documentário denominado "A Descoberta da Amazônia pelos Turcos Encantados" (2005) tenha afirmado que os turcos se ajuremaram despindo as roupas de turco e vestindo a roupa de indios" (Pai Tayandô, Sacerdote Falecido do Tambor de Mina).

Para as entidades turcas, em momento de festividade é realizada a chamada bancada da Turquia com oferendas secas como grãos, frutas secas, damasco, bebida forte como conhaque, whisky, pão sem fermento e especiarias. Os caboclos turcos não recebem sacrifício de animal.

Todas as famílias no Tambor de Mina possuem cores específicas que se fazem presente nas guias ${ }^{47}$, rosários $^{48}$, decoração das festas e marcações ${ }^{49}$ religiosas. Assim como no Maranhão, as cores da família de Turquia são vermelho, verde e amarelo que representam o sangue das batalhas cruzadas, as matas do Brasil nação de adoção dessas entidades - e as riquezas minerais dessa nação. Faz -se importante registrar que a cor vermelha é a cor da bandeira da Turquia e o amarelo e verde se fazem presente na bandeira brasileira, indicando a sustentação de uma identidade plural que faz referência a nação que essas entidades carregam no nome e ao país onde são cultuados e onde estão seus espaços de "encantaria". As três cores em conjunto (verde, vermelho e amarelo), compõe a bandeira oficial da Mauritânia. Esta última, reproduz em amarelo, a simbologia da bandeira turca que é a lua crescente e a estrela (também presente na bandeira do Brasil).

A estrela, representada, pelo signo Salomão é o maior símbolo da família de Turquia, geralmente carregado ao pescoço na extremidade dos rosários das entidades turcas. Segundo a narrativa o triângulo cujo

\footnotetext{
${ }^{47}$ Espécie de colares sagrados que os religiosos carregam ao pescoço, representando as entidades que incorporam bem como às famílias a que essas entidades pertencem. Podem indicar também "pelo número de pernas" (1, 3, 7 ou 21 fios), a posição que o indivíduo ocupa na hierarquia do terreiro e o seu tempo de iniciação.

${ }^{48}$ Mesmo que Guia, contendo um crucifixo, medalha de santo, signo Salomão e outros símbolos na extremidade. Usada especificamente no Tambor de Mina.

${ }^{49}$ Nome dado a estampa das saias das dançantes e da blusa dos dançantes em momento ritual.
} 


\section{Uma experiência cruzada pelas águas do Pará: \\ A família de Turquia no tambor de Mina}

vértice está voltado para cima representa a "trindade da Turquia" e o de vértice virado para baixo a "esquerda" desta família. De acordo com o dicionário Priberan Org (2020) trata-se de:

\footnotetext{
“1. Espécie de talismã, formado por dois triângulos sobrepostos, geralmente de metal, entr elaçados em forma de estrela de seis pontas, a que o vulgo atribui virtudes contra os malefícios.

2. Estrela formada por dois triângulos, equiláteros sobrepostos, que simboliza o judaísmo e a ESTRELA DE .DAVI” (HTTPS://DICIONARIO.PRIBERAM.ORG/SIGNO-DE-SALOMÃO, 2020)
}

Outros símbolos da família de Turquia e também pode ser carregado na extremidade dos rosários desses encantados, são elementos ligados ao mar, mais especificamente à navegação, a exemplo da âncora. Não há referência a símbolos do mar enquanto natureza, como a concha que representa a orixá Iemanjá, por exemplo. O mar aparece através dos símbolos náuticos, o que remonta a história dos chamados mouros quer seja pela guerra, contra os cristãos nas famosas cruzadas, quer seja pela economia, considerando que esses povos dominavam as rotas de comércio mediterrâneo das especiarias.

\section{NOS ALINHAVOS DA MEMÓRIA HISTÓRICA O IMAGINÁRIO CONSTROI UMA EPOPÉIA DE REVERÊNCIA AO MAR: NOTAS CONCLUSIVAS}

A título de conclusão apontaremos propostas de desdobramentos deste artigo. Uma mitologia tão rica quanto a acima relatada, merece análise mais aprofundada em artigos posteriores pois sua complexidade não cabe nos limites destas páginas. O processo de ajuremamento merece ser revisto a luz do conceito de identidade nacional, o simbolismo das cores acima citadas, precisam de detalhamento bem como o vínculo com a simbologia turca, brasileira e da Mauritânia.

No entanto o elemento mais importante desta mitologia, é a nosso ver, o simbolismo da água, que não aparece por si só, mas representada pela atividade náutica. Assim como a mitologia referente a realeza lusitana, já estudada em momentos anteriores (LUCA, 2020), os encantados da família de Turquia também possuem forte ligação com a navegação. As narrativas mitológicas bem como as doutrinas cantadas entoam epopeias que precisam de melhor atenção. A doutrina clássica da família de Turquia nos diz:

\footnotetext{
"Seu Turquia Vamos ao Mar

Correr o mundo geral

Ora vamos louvar a Maria

Averê Pombo do ar"
}

Essa referência possui caráter polissêmico. Pode aludir a metáfora das batalhas cruzadas que aconteciam por entre o mar Mediterrâneo uma vez que era este o limiar entre o mundo cristão ibérico e o mundo conhecido como "pagão" africano. O mar também era fonte de poder econômico e disputas comerciais entre esses dois povos. Não esqueçamos que a dominação do Mediterrâneo pelos chamados Turcos Otomanos obrigou os portugueses a se lançar em busca de um novo caminho para as Índias a fim de dar procedência ao lucrativo comércio das especiarias. 


\section{Uma experiência cruzada pelas águas do Pará: \\ A família de Turquia no tambor de Mina}

Ao dominar o mar mediterrâneo os norte-africanos, aqui chamados de turcos, afastaram os lusitanos das rotas de comércio mas também os obrigaram a dar início a jornada das chamadas grandes navegações e consequentemente às expedições desbravadoras e colonizadoras pelo atlântico. Uma das condições para que isso ocorresse foi a chamadas guerras de reconquista que tinha por objetivo expulsar os mesmos mouros da Penísula Ibérica, haja visto que esta região foi dominada por eles durante muitos séculos.

É no atlântico que reside o segundo eixo de sentido do mar para os turcos mitológicos. O atlântico foi o oceano que separou, durante o período colonial a África, a Europa e o Brasil. Se pensarmos numa geografia da colonização, a colônia acabou servindo de vértice de confluência desses dois continentes, seus povos e suas

culturas. E neste sentido o mar é o alinhavo entre experiências históricas de temporalidades diferentes. Esta costura ata a experiência da cruzada, imaginário lusitano e tráfico negreiro.

Gilbert Durand (1996) recorda a pena de Camões descrevendo-o como uma "face humana com olhar obstinadamente voltado para o oceano" (pp. 197). Se, como foi visto anteriormente (Luca, 2010) Portugal caracteriza-se por ser uma nação de conquistadores, essa é uma história que possui no mínimo duas versões: a lusitana e a mourisca. O mesmo imaginário náutico é comungado pelos turcos. A história "luso-mauritana" foi marcada por alguns momentos importantes a destaque ao processo de reconquista portuguesa, expansão ultramarina e pela longa jornada de combate aos "infiéis" no norte do continente africano.

O oceano é o elemento que povoa o imaginário dos dois grupos e o imaginário desses povos se define como uma eterna luta do homem contra a água. Vencer esta "muralha viva das águas e dos ventos" (Coelho, 1998: 42) significa galgar triunfo. Para os portugueses históricos e para os turcos mitológicos:

"Os oceanos se transformaram em cenário de súplicas e altar da liturgia, em orago dos
santos chamados nas horas graves do nauta enfrentar a negra tormenta e triunfar sobre a
morte no abismo sem fim do desconhecido mar" (Coelho, 1998:43).

Não é possível esquecer que os mouros aqui referidos são africanos residentes no norte do continente e para a memória africana, o mar aparece como o elemento de separação entre o continente de origem e o novo mundo do trabalho. Pelo mar o negro foi arrancado de uma cultura originária e inserido em outra completamente sincrética e imposta.

Muitas vezes foi cemitério de quem embarcou mas não completou a viagem tendo a vida ceifada e jogada ao mar. Representou também a transformação da condição social desses povos que muitas vezes saiam da realeza para servidão sofrendo mudança de nome, de religião, de cultura, ressignificação de cosmogonia e cosmologia e sobretudo resistência simbólica através de uma religião reconstruída a partir da diversidade cultural encontrada e enraizada no novo mundo.

Em função disso o sacerdote refere-se ao mar como representação das lágrimas africanas dizendo:

"Tudo que vem da África é assim... Tem uns que cantam com alegria e tem uns que cantam com tristeza. Por exemplo assim: - Não tem a África, do além mar, o continente que ficou afastado? Então eles (os turcos) são muito ligados nisso. Muitos vieram para cá, muitos já 


\section{Uma experiência cruzada pelas águas do Pará: \\ A família de Turquia no tambor de Mina}

moravam no Brasil e aprenderam coisas do Brasil com seu Rei da Turquia. Seu Rei da Turquia não morava (originalmente) no Brasil. Ele era Africano e veio para cá. Seu rei da Turquia lamenta ter deixado as origens para ter vindo para cá" (Pai Mosaniel Reis Costa, Sacerdote do Tambor de Mina)

Com a poesia desta narrativa encerramos o texto deixando os alinhavos dessa epopeia entreabertos a outras costuras simbólicas e teóricas que não foram possíveis de serem cerzidas nas páginas desse artigo.

\section{REFERÊNCIAS BIBLIOGRÁFICAS}

MOURA, C. E. M. (Org). Meu Sinal Está no Teu Corpo: Escrito sobre a Religião dos Orixás. São Paulo: EDICON-EDUSP, 1989.

CLIFFORD, James. A Experiência Etnográfica: Antropologia e Literatura no Século XX. Rio de Janeiro: UFRJ, 2002.

COELHO, Geraldo Mártires. Uma Crônica do Maravilhoso: Legenda, Tempo e Memória no Culto de Nossa Senhora de Nazaré. Belém: IOEPA, 1998.

DURKHEIM, Émile. As Regras do Método Sociológico. Lisboa: Presença, 2004.

DURAND, Gilbert. Imagens e Reflexos do Imaginário Português. Lisboa: Hugen, 1987.

Campos do Imaginário. Lisboa: Instituto Piaget, 1996.

ELIADE, Mircea. Tratado de História das Religiões. São Paulo: Martins Fontes, 1998.

ELIAS, Norbert. Sociedade de Corte. Rio de Janeiro: Jorge Zahar, 2001.

FERREIRA, Euclides. O Terreiro da Turquia. São Luís: (mimeo), 1987.

FERRETTI, Mundicarmo. Desceu na Guma: O Caboclo no Tambor de Mina. São Luís - A Casa de FanthiAshanti. São Luís: SIOGE, 1993

. "Rei da Turquia, o Ferrabrás de Alexandria? A Importância de Um Livro na Mitologia do Tambor de Mina”. In: MOURA, Carlos Eugênio M. Meu Sinal está no teu Corpo: Escritos sobre a Religião dos Orixás. São Paulo: EDICOM - EDUSP, 1989.

. "Repensando o Turco na Mina". In: Padé. Salvador: CERN, s/d.

GEERTZ, Clifford. A Interpretação das Culturas. Rio de Janeiro: Kloogan S/A, 1989.

LEACOCK, Seth \& LEACOCK, Ruth. Spirits of the Deep: A Study of an Afro-Brasilian Cult. Nova York: Anchor Book, 1972.

LUCA, Taissa Tavernard de. Devaneios da Memória: A História dos Cultos Afro-Brasileiros em Belém do Pará. (Trabalho de Conclusão de Curso). Belém: UFPA, 1999.

Tem Branco na Guma.(Tese de Doutorado). Belém: UFPA, 2010.

VERGOLINO, Anaíza. O Tambor das Flores. (Dissertação de Mestrado). Campinas: UNICAMP, 1976. . Religiões Africanas no Pará: Uma Tentativa de Reconstrução Histórica. Amazônia.

Belém: IPAR, Ano 2, No 2, 2000. 


\section{Uma experiência cruzada pelas águas do Pará:}

A família de Turquia no tambor de Mina

. "Os Cultos Afro no Pará". In: FONTES, Edilza Joana (org.). Contando a História do Pará: Diálogos entre a História e a Antropologia.. Belém: E. Motion, 2003.

"Ponto de Santo: A Música e o Pará"(Encarte de CD ). Belém: SECULT, 2003.

WEBER, Max. Economia e Sociedade. Brasília: Editora da UnB. São Paulo: IOSP, 1999.

Texto recebido em: 18/11/2020

Texto aprovado em: $25 / 11 / 2020$ 